\title{
Activities of the enzymes of the Ehrlich pathway and formation of branched-chain alcohols in Saccharomyces cerevisiae and Candida utilis grown in continuous culture on valine or ammonium as sole nitrogen
} source

\author{
Simon Derrick and Peter J. LARGe*
}

Department of Applied Biology, The University of Hull, Hull HU6 7RX, UK

(Received 5 April 1993; revised 4 June 1993; accepted 1 July 1993)

\begin{abstract}
Valine aminotransferase, a key enzyme in both biosynthesis and breakdown of branched-chain amino acids, showed consistently higher activity in Candida utilis grown in continuous culture than in Saccharomyces cerevisiae, while pyruvate decarboxylase and alcohol dehydrogenase, the other two enzymes of the Ehrlich pathway of branchedchain alcohol formation, were lower in activity. By spheroplast lysis, it was shown that valine aminotransferase followed the distribution of pyruvate decarboxylase in being located in the cytosol. Replacement of ammonium as nitrogen source by valine during conditions of carbon or nitrogen limitation caused increased specific activities of these three enzymes in $S$. cerevisiae, but (with one exception) decreased those of $C$. utilis. Of the metabolites accumulating in the culture medium, little or no ethanol or branched-chain alcohols were present during carbonlimited growth of either organism, but the change to nitrogen limitation resulted in increases in concentration of 20- to 100-fold in pyruvate, acetate and non-pyruvate keto acids as well as the accumulation of branched-chain alcohols in both organisms, and of ethanol, ethyl acetate and glycerol in $S$. cerevisiae. When valine was the limiting nitrogen source, there was an increase in non-pyruvate keto acids and a 10- to 16-fold increase in 2-methylpropanol. Total branched-chain alcohols formed under nitrogen limitation were 2-fold higher in $S$. cerevisiae than in C. utilis, irrespective of nitrogen source. Accumulation of branched-chain alcohols, ethanol, acetate and glycerol was also observed during carbon-limited growth of $S$. cerevisiae with valine as nitrogen source at dilution rates above the critical rate for transition to respirofermentative growth. Less than $70 \%$ of the valine carbon metabolized during growth of $S$. cerevisiae and only $15 \%$ of that used during growth of $C$. utilis was recovered in identified metabolic products. Even allowing for losses by volatilization during aeration, this suggests that a significant amount of the valine is being metabolized by a route or routes other than the Ehrlich pathway, possibly via the action of branchedchain 2-keto acid dehydrogenase. The molar growth yield for the nitrogen source under either carbon or nitrogen limitation was significantly lower for growth on valine than for growth on ammonium, suggesting that breakdown of valine requires more energy. It is evident that not all the enzymes involved in branched-chain amino acid metabolism in yeasts have yet been identified, nor are their interactions properly understood.
\end{abstract}

\section{Introduction}

'Higher' alcohols (fusel alcohols) are the most abundant volatile flavour components in alcoholic beverages (Engan, 1981). They include propan-1-ol, 2methylpropan-1-ol (isobutanol), (S)-(-)-2-methylbutan1-ol (optically active amyl alcohol), 3-methylbutan-1-ol (isoamyl alcohol) and 2-phenylethanol (phenethyl alcohol). Acetate esters, which have even lower flavour

*Author for correspondence. Tel. +44482 465245; fax +44482465458 . thresholds (MacDonald et al., 1984), are also formed from these compounds. The properties and formation of both these groups have been reviewed by Berry \& Watson (1987).

Fusel alcohols are formed by all the yeast species that have been examined (Guymon et al., $1961 a, b$ ), and are not by-products of ethanol formation. They are derived from the carbon skeletons of the corresponding amino acids by a route first postulated by Ehrlich (1907) (see also Webb \& Ingraham, 1963), the enzymic basis of which was established by SentheShanmuganathan (1960). In the case of the branched-chain alcohols, this involves 
three enzymes: a branched-chain amino acid aminotransferase (EC 2.6.1.42), pyruvate decarboxylase (EC 4.1.1.1) which converts the resulting branchedchain keto acid to the branched-chain aldehyde with one carbon atom less, and alcohol dehydrogenase (EC 1.1.1.1), which catalyses the NADH-dependent reduction of this aldehyde to the corresponding primary alcohol. It has been shown for wine yeasts that the isoenzyme involved in branched-chain aldehyde reduction is the classical fermentative isoenzyme ADH-1 (Singh \& Kunkee, 1977). Fusel alcohols are formed whether yeast is grown using amino acids as nitrogen source, as in wort, or with ammonium salts (Ingraham \& Guymon, 1960), but the presence of glucose is essential (SentheShanmuganathan, 1960). In the first case the carbon skeletons arise from the wort amino acids, in the second case by de novo synthesis from glucose (see below). Fusel alcohol formation is promoted by aerobiosis (Guymon et al., 1961 b; Quain \& Duffield, 1985).

Previous studies on fusel alcohol and ester formation in continuous culture (Watson \& Hough, 1969; Berry \& Chamberlain, 1986), have led to the suggestion that control of the production of branched-chain aldehydes lies in the supply of branched-chain keto acids (Watson \& Hough, 1969). Woodward \& Cirillo (1977) have shown that large amounts of these keto acids accumulate in radioactive form in the medium if ${ }^{14} \mathrm{C}$-labelled branched-chain amino acids are administered to prolinegrown Saccharomyces cerevisiae in the presence of glucose, though few are formed if the yeast is grown on ammonium or if glucose is absent. In the formation of branched-chain keto acids from the corresponding amino acids, one or more branched-chain amino acid aminotransferases (Bode \& Birnbaum, 1988) must play a key role, and during growth on ammonium where the branched-chain keto acids are synthesized de novo via acetolactate or acetohydroxybutyrate, the same aminotransferase(s) will compete with pyruvate decarboxylase for the keto acids. This competition might be controlled by subcellular compartmentation (Bigelis et al., 1983). No continuous culture studies have been performed on the distribution of branched-chain amino acid aminotransferase activity in yeasts.

Until recently, it was assumed (e.g. Woodward \& Cirillo, 1977; Bigelis et al., 1983; Large, 1986) that the Ehrlich pathway was the major, if not the only, route for the metabolic transformation of branched-chain amino acids in S. cerevisiae, whereas Candida utilis was assumed to break down the carbon skeleton completely (see references in Large, 1986). Recent work however (Dickinson \& Dawes, 1992) has shown that the branched-chain 2-keto acid dehydrogenase multienzyme system (EC 1.2.4.4) found in bacteria (Massey et al., 1976) is also present in $S$. cerevisiae. Any work on fusel alcohol formation thus needs to address the problem of the possible decarboxylation of metabolites of branchedchain amino acids via more than one route.

The objectives of the present work were to examine the effect of changes in the glucose concentration, the nitrogen source and the growth rate on (1) the activities and subcellular location of the three enzymes of the Ehrlich pathway (and a few other key enzymes) in two yeast species, $S$. cerevisiae and $C$. utilis, growing in aerobic continuous culture on defined medium, and (2) the steady-state concentrations of 2-methylpropanol, 2methylbutanol and 3-methylbutanol, as well as several other metabolic products. This permits for the first time a direct comparison under identical growth conditions of these parameters for two yeasts of different physiological type, Crabtree-positive and Crabtree-negative (Alexander \& Jeffries, 1990).

\section{Methods}

Micro-organisms and growth conditions. Saccharomyces cerevisiae CBS 8066 and $C$. utilis CBS 621 were maintained on glucose $(0.5 \%)$ /yeast extract $(0.5 \%) /$ malt extract $(2 \%, \mathrm{w} / \mathrm{v}) / \operatorname{agar}(2 \%, \mathrm{w} / \mathrm{v})$ slopes. They were grown aerobically on defined medium in chemostat cultures (working volume $750 \mathrm{ml}$ ) at $30^{\circ} \mathrm{C}$, at a dilution rate of $0 \cdot 1 \mathrm{~h}^{-1}$ unless otherwise stated, with the $\mathrm{pH}$ controlled to 5.0 by automatic addition of $1 \mathrm{M}-\mathrm{NaOH}$. The stirrer speed was 1000 r.p.m. and the gas flow rate was $600 \mathrm{ml}$ air $\mathrm{min}^{-1}$. The medium was that of Bruinenberg et al. (1983) except that Bevaloid 6560 defoamer (Bevaloid Ltd) was used. The carbon source was glucose. The oxygen tension was monitored with an autoclavable galvanic oxygen electrode and maintained between 70 and $100 \%$ of air saturation. For glucoselimited growth, the concentration was $27.8 \mathrm{mM}\left(5 \mathrm{~g}^{-1}\right)$, and for nitrogen-limited growth, $278 \mathrm{~mm}\left(50 \mathrm{~g}^{-1}\right)$. The nitrogen source was either ammonium sulphate $(10 \mathrm{~mm})$ or valine $(20 \mathrm{~mm})$. The medium was sterilized by filtration through a Sartorius Sartobran-PH filter cartridge (pore size combination: $0 \cdot 45 / 0 \cdot 2 \mu \mathrm{m}$ ). Growth was measured as optical density at $540 \mathrm{~nm}$ and converted to dry weight using a calibration curve for each organism. Samples were removed from the vessel in screw-top bottles sealed by a rubber liner, centrifuged at $5^{\circ} \mathrm{C}$, and the supernatants stored in screw-top bottles at $-18^{\circ} \mathrm{C}$.

Harvesting of cells and preparation of cell-free extracts. Cells were centrifuged at $16000 \mathrm{~g}$ at $5^{\circ} \mathrm{C}$, washed in water, and used immediately for cell fractionation work. Otherwise, they were stored at $-18^{\circ} \mathrm{C}$ until required for enzyme assays. Extracts were prepared by suspending the cells in 2 vols $150 \mathrm{~mm}$-potassium phosphate buffer, $\mathrm{pH} 6.5$ containing

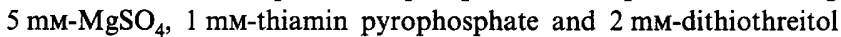
(modified from Van Urk et al., 1989) and passing three times through a French pressure cell at $4^{\circ} \mathrm{C}$. The resulting material was centrifuged for $15 \mathrm{~min}$ at $40000 \mathrm{~g}$ at $5^{\circ} \mathrm{C}$.

Preparation of spheroplasts. For $S$. cerevisiae, $1 \mathrm{~g}$ wet wt of cells was preincubated in $5 \mathrm{ml} 2.5 \mathrm{~mm}$-dithiothreitol in $0.1 \mathrm{M}$-Tris $/ \mathrm{HCl}, \mathrm{pH} 9$ at $28^{\circ} \mathrm{C}$ for $20 \mathrm{~min}$ (Skoneczny et al., 1988). Cells were then pelleted $(12000 \mathrm{~g}, 10 \mathrm{~min})$, washed with spheroplast buffer A (2 M-sorbitol, $1 \mathrm{mM}$-EDTA in $5 \mathrm{~mm}$-MOPS, pH 7.2) and resuspended in $2 \mathrm{ml}$ of buffer A containing $1 \%(\mathrm{v} / \mathrm{v})$ 2-mercaptoethanol and $2 \mathrm{mg}$ Lyticase (Sigma) (Scott \& Schekman, 1980) (g wet wt of cells) ${ }^{-1}$. The suspension was incubated at $30^{\circ} \mathrm{C}$ and spheroplast formation monitored (as described by Bruinenberg et al., 1985) until 50-70\% of the cells had become spheroplasts, or non-osmotic lysis was evident. Spheroplasts of $C$. utilis were prepared by the method of Bruinenberg et al. (1985). Cells were 
harvested and washed with spheroplast buffer B ( 2 M-sorbitol, $1 \mathrm{~mm}$ EDTA, $1 \mathrm{~mm}-\mathrm{MgCl}_{2}$ in $25 \mathrm{~mm}$-potassium phosphate, $\mathrm{pH} 7.5$ ) and resuspended in $2 \mathrm{ml}$ of buffer B containing $2 \mathrm{mg}$ Lyticase ( $\mathrm{g}$ wet wt of cells $)^{-1}$. The suspension was incubated at $30^{\circ} \mathrm{C}$ and spheroplast formation monitored. With both organisms, the spheroplasts were harvested by centrifugation at $3000 \mathrm{~g}$ for $10 \mathrm{~min}$ at $5^{\circ} \mathrm{C}$, washed twice and resuspended in $10 \mathrm{ml}$ of appropriate spheroplast buffer.

Lysis of spheroplasts and isolation of subcellular fractions. Spheroplasts were lysed by gentle osmotic disruption, based on method IV of Bruinenberg et al. (1985) in which samples $(10 \mathrm{ml})$ were dialysed at $15^{\circ} \mathrm{C}$ against 5 litres of spheroplast buffer not containing sorbitol and the decrease in sorbitol concentration was monitored with a refractometer until the critical concentration was reached at which cell lysis was maximal and organelle lysis had not quite begun ( $(0.9 \mathrm{M}$ for $S$. cerevisiae and $0.7 \mathrm{~m}$ for $C$. utilis). Dialysis was then stopped and whole cells and unbroken spheroplasts were removed by two centrifugations at $1930 \mathrm{~g}$ for $15 \mathrm{~min}$ at $5{ }^{\circ} \mathrm{C}$. The supernatant $(\mathrm{T})$ was then centrifuged at $12000 \mathrm{~g}$ for $10 \mathrm{~min}$ to provide pellet $P_{1}$ and the supernatant subjected to $45000 \mathrm{~g}$ for $20 \mathrm{~min}$ to provide $\mathrm{P}_{2}$ and a final supernatant $\mathrm{S}$. $\mathrm{P}_{1}$ and $P_{2}$ were washed and resuspended in 1 vol. of spheroplast buffer containing the appropriate sorbitol concentrations. All samples were stored at $-15^{\circ} \mathrm{C}$ and enzyme activity measured within 2 weeks.

Enzyme assays. Enzyme assays on samples from steady-state cultures are averages of duplicate determinations. The error in most assay rate measurements was $\pm 10 \%$. Assays were all performed in $1 \mathrm{ml}$ reaction volumes at $25^{\circ} \mathrm{C}$. One unit of enzyme activity is the amount required to catalyse the transformation of $1 \mu \mathrm{mol}$ of substrate or the formation of $1 \mu \mathrm{mol}$ of product $\mathrm{min}^{-1}$. Assays were performed according to the following methods: alcohol dehydrogenase (McGill \& Dawes, 1971), pyruvate decarboxylase and citrate synthase (Clarkson et al., 1991), alkaline phosphatase (Green \& Large, 1984), NAD- and NADPdependent glutamate dehydrogenases (Doherty, 1970), glucose-6phosphate dehydrogenase (Bergmeyer, 1963; modified by the use of pH 8 and with the addition of 0.83 units of 6-phosphogluconate dehydrogenase per $\mathrm{ml}$ of reaction mixture). Valine aminotransferase was assayed as follows (based on Large \& Robertson, 1988): $20 \mathrm{~mm}-$ sodium 2-oxoglutarate was incubated with $0.1 \mathrm{~mm}$-pyridoxal phosphate, $50 \mathrm{~mm}$-potassium phosphate buffer, $\mathrm{pH} 7 \cdot 8$, extract and water (final volume, $1 \mathrm{ml}$ ). The reaction was started by addition of $20 \mathrm{mM}-\mathrm{L}-$ valine, and stopped after $10 \mathrm{~min}$ by heating for $2 \mathrm{~min}$ at $100^{\circ} \mathrm{C}$. Samples were removed and the glutamate measured with Boehringer test-combination 139092. The activity was calculated from the difference in glutamate between $10 \mathrm{~min}$ and zero time samples.

Chemical determinations. All medium analyses were based on duplicate determinations. Samples were thawed slowly at $5{ }^{\circ} \mathrm{C}$, still in sealed bottles. Pyruvate was measured enzymically from the change in absorbance at $340 \mathrm{~nm}$ when $0.2 \mathrm{~mm}-\mathrm{NADH}, 120 \mathrm{~mm}$-triethanolamine/ $\mathrm{HCl}, \mathrm{pH} 7 \cdot 6$, diluted sample and $9 \cdot 1$ units of rabbit muscle lactate dehydrogenase (LDH) (Sigma) were incubated together. Total keto acids were measured as 2,4-dinitrophenylhydrazones (Aki \& Ichihara, 1970), and non-pyruvate keto acids were obtained by subtraction of the pyruvate concentration. Acetate was measured using Boehringer food analysis kit 148261 . Since samples for glycerol determination contained high concentrations of pyruvate, the latter was removed by converting it to lactate by incubating $0.5 \mathrm{ml}$ of diluted sample with $1 \mu \mathrm{mol} \mathrm{NADH}$ and 18 units of $\mathrm{LDH}$ in $0.2 \mathrm{M}$-triethanolamine $/ \mathrm{HCl}$ buffer, $\mathrm{pH} 7.6$ in a total volume of $1 \mathrm{ml}$ at $25^{\circ} \mathrm{C}$ for $30 \mathrm{~min}$. The $\mathrm{LDH}$ was then inactivated by heating for $2 \mathrm{~min}$ at $100^{\circ} \mathrm{C}$. After cooling, the glycerol content of the sample was determined with Boehringer test-combination 148270 . Ethanol and glucose were determined as described by Clarkson et al. (1991). Branched-chain alcohols and ethyl acetate were extracted from the growth medium into three successive equal volumes of diethyl ether after addition of butan-2-ol (2.75 mM) as internal standard. After concentration of the combined ethereal extracts, samples were submitted to GLC on a Supelco Carbopack C/0.2\% Carbowax 1500 column $(1.5 \mathrm{~m} \times 4 \mathrm{~mm})$ (Supelchem UK Ltd) (injection port and detector temperatures, $200^{\circ} \mathrm{C}$; column temperature, $115^{\circ} \mathrm{C}$ ), with $\mathrm{N}_{2}$ carrier gas (flow rate $30 \mathrm{ml} \mathrm{min}^{-1}$ ) with flame-ionization detection and quantified by comparison of peak area with a standard curve for butan-2-ol. Peaks were identified by comparison of their retention times with authentic standards, and in some cases confirmed by GLC-MS. Ammonium was measured by the indophenol method (Chaney \& Marbach, 1962), and valine with 2,4,6-trinitrobenzenesulphonic acid (Satake et al., 1960). Protein was determined by the Bradford (1976) method.

\section{Results and Discussion}

Saccharomyces cerevisiae and Candida utilis were grown in defined medium in aerobic continuous culture at glucose concentrations of $27.8 \mathrm{~mm}$ (carbon-limiting) and $278 \mathrm{~mm}$ (nitrogen-limiting) with either $20 \mathrm{mM}$ ammonium or $20 \mathrm{~mm}$-valine as sole nitrogen source. The cells were examined for the activities and subcellular distribution of enzymes of the Ehrlich pathway, and the biomass, substrate and product concentrations of the medium were measured.

\section{Specific activities of enzymes of the Ehrlich pathway and other key enzymes in crude extracts during growth on ammonium as nitrogen source}

In $S$. cerevisiae, with ammonium as nitrogen source, the change to nitrogen limitation, which induces respirofermentative growth (ethanol formation under aerobic growth conditions; Alexander \& Jeffries, 1990), produced increases in the specific activities of valine aminotransferase and pyruvate decarboxylase, compared with glucose-limited growth, whereas NADP-linked glutamate dehydrogenase was unchanged and alcohol dehydrogenase, NAD-linked glutamate dehydrogenase and glucose-6-phosphate dehydrogenase decreased (Table 1). In $C$. utilis, although respirofermentative growth does not occur at high glucose concentrations, the effect of the change to nitrogen limitation on enzyme activities was similar, except that NADP-linked glutamate dehydrogenase and valine aminotransferase were decreased and, of the other enzymes of the Ehrlich pathway, the specific activity of pyruvate decarboxylase was elevated and alcohol dehydrogenase was unchanged. With the exception of these last two enzymes, enzyme specific activities in $C$. utilis were much higher than in $S$. cerevisiae under all the growth conditions shown in Table 1.

\section{Specific activities of enzymes of the Ehrlich pathway and other key enzymes in crude extracts during growth on valine as nitrogen source}

During growth with valine as nitrogen source, all the enzymes of the Ehrlich pathway were elevated in $S$. 
Table 1. Specific activities of enzymes of the Ehrlich pathway and other key enzymes during growth of Saccharomyces cerevisiae and Candida utilis in continuous culture under carbon or nitrogen limitation

\begin{tabular}{|c|c|c|c|c|}
\hline \multirow[b]{3}{*}{ Enzyme } & \multicolumn{4}{|c|}{ Specific activity [nmol $\left.\min ^{-1}(\mathrm{mg} \text { protein })^{-1}\right]$} \\
\hline & \multicolumn{2}{|c|}{ Ammonium as nitrogen source } & \multicolumn{2}{|c|}{ Valine as nitrogen source } \\
\hline & $\begin{array}{l}\text { Carbon } \\
\text { limitation }\end{array}$ & $\begin{array}{c}\text { Nitrogen } \\
\text { limitation }\end{array}$ & $\begin{array}{l}\text { Carbon } \\
\text { limitation }\end{array}$ & $\begin{array}{c}\text { Nitrogen } \\
\text { limitation }\end{array}$ \\
\hline \multicolumn{5}{|l|}{ (a) Saccharomyces cerevisiae } \\
\hline Valine aminotransferase & 29 & 93 & 682 & 122 \\
\hline Pyruvate decarboxylase & 180 & 290 & 372 & 459 \\
\hline Alcohol dehydrogenase & 597 & 207 & 699 & 248 \\
\hline Glutamate dehydrogenase (NAD) & 20 & 6 & 101 & 76 \\
\hline Glutamate dehydrogenase (NADP) & 965 & 995 & 511 & 323 \\
\hline Glucose-6-phosphate dehydrogenase & 93 & 45 & 163 & 72 \\
\hline \multicolumn{5}{|l|}{ (b) Candida utilis } \\
\hline Valine aminotransferase & 1840 & 747 & 1620 & 2740 \\
\hline Pyruvate decarboxylase & 42 & 204 & 31 & 106 \\
\hline Alcohol dehydrogenase & 235 & 283 & 22 & 8 \\
\hline Glutamate dehydrogenase (NAD) & 103 & 28 & 1450 & 256 \\
\hline Glutamate dehydrogenase (NADP) & 3000 & 1300 & 458 & 365 \\
\hline Glucose-6-phosphate dehydrogenase & 1520 & 826 & 1130 & 993 \\
\hline
\end{tabular}

Table 2. Subcellular distribution in pellets $\left(P_{1}\right.$ and $\left.P_{2}\right)$ and $45000 \mathrm{~g}$ supernatant $(S)$ of enzymes of the Ehrlich pathway in Saccharomyces cerevisiae and marker enzymes

Data are from a representative spheroplast preparation. Essentially similar figures were obtained on other preparations from both organisms. The first column is units of enzyme activity or $\mathrm{mg}$ protein in the total spheroplast lysate. The second column is $100 \times\left[\mathrm{P}_{1}+\mathbf{P}_{2} /\left(\mathrm{P}_{1}+\mathrm{P}_{2}+\mathrm{S}\right)\right]$, the third column is $100 \times\left[S /\left(\mathrm{P}_{1}+\mathrm{P}_{2}+\mathrm{S}\right)\right]$ and the fourth column $100 \times\left[\left(\mathbf{P}_{1}+\mathbf{P}_{2}+\mathbf{S}\right) / \mathrm{T}\right]$, where $\mathbf{P}_{1}, \mathbf{S}$ etc., are the total activities in the respective fractions.

\begin{tabular}{|c|c|c|c|c|c|c|c|c|}
\hline \multirow[b]{2}{*}{ Enzyme } & \multicolumn{4}{|c|}{ Carbon-limited } & \multicolumn{4}{|c|}{ Nitrogen-limited } \\
\hline & $\begin{array}{l}\text { Total } \\
\text { activity } \\
\text { (T) }\end{array}$ & $\underset{(\%)}{P_{1}+P_{2}}$ & $\begin{array}{c}S \\
(\%)\end{array}$ & $\begin{array}{c}\text { Recovery } \\
(\%)\end{array}$ & $\begin{array}{l}\text { Total } \\
\text { activity } \\
\text { (T) }\end{array}$ & $\underset{(\%)}{\mathbf{P}_{1}+\mathbf{P}_{2}}$ & $\begin{array}{c}S \\
(\%)\end{array}$ & $\begin{array}{c}\text { Recovery } \\
(\%)\end{array}$ \\
\hline \multicolumn{9}{|l|}{ Ammonium as nitrogen source } \\
\hline Citrate synthase & 0.9 & 96 & 4 & 121 & $0 \cdot 2$ & 51 & 49 & 113 \\
\hline Alkaline phosphatase & 0.4 & 11 & 89 & 58 & $2 \cdot \overline{3}$ & 4 & 96 & 82 \\
\hline Valine aminotransferase & $2 \cdot 5$ & 12 & 88 & 89 & $3 \cdot 3$ & 5 & 95 & 100 \\
\hline Pyruvate decarboxylase & $15 \cdot 6$ & 1 & 99 & 125 & $15 \cdot 3$ & 13 & 87 & 125 \\
\hline Alcohol dehydrogenase & $50 \cdot 6$ & 3 & 97 & 115 & $7 \cdot 2$ & 5 & 95 & 42 \\
\hline Protein & $84 \cdot 6$ & 6 & 94 & 105 & $34 \cdot 9$ & 4 & 96 & 100 \\
\hline \multicolumn{9}{|l|}{ Valine as nitrogen source } \\
\hline Citrate synthase & 6.5 & 55 & 45 & 77 & $1 \cdot 3$ & 37 & 63 & 93 \\
\hline Alkaline phosphatase & 1.9 & 9 & 91 & 64 & $2 \cdot 4$ & 7 & 93 & 80 \\
\hline Valine aminotransferase & $34 \cdot 9$ & 4 & 96 & 64 & $8 \cdot 3$ & 4 & 96 & 56 \\
\hline Pyruvate decarboxylase & $8 \cdot 6$ & 3 & 97 & 70 & $31 \cdot 2$ & 0 & 100 & 77 \\
\hline Alcohol dehydrogenase & $30 \cdot 1$ & 3 & 97 & 59 & 16.9 & 1 & 90 & 91 \\
\hline Protein & 50.0 & 7 & 93 & 99 & $67 \cdot 9$ & 3 & 97 & 79 \\
\hline
\end{tabular}

cerevisiae. Nitrogen limitation led to lower valine aminotransferase activity in $S$. cerevisiae compared with carbon-limited conditions but in C. utilis it was higher. In the latter organism, alcohol dehydrogenase and NADP-linked glutamate dehydrogenase were much lower under both growth conditions when valine was the nitrogen source (Table 1). The latter would be expected, because the enzyme will have no biosynthetic role during growth on valine. NAD-linked glutamate dehydrogenase in contrast was elevated in both yeasts under these conditions, as would be expected in view of its known role (Miller \& Magasanik, 1990) of releasing ammonia 
Table 3. Subcellular distribution in pellets $\left(P_{1}\right.$ and $\left.P_{2}\right)$ and $45000 \mathrm{~g}$ supernatant $(S)$ of enzymes of the Ehrlich pathway in Candida utilis and marker enzymes

See legend to Table 2.

\begin{tabular}{|c|c|c|c|c|c|c|c|c|}
\hline \multirow[b]{2}{*}{ Enzyme } & \multicolumn{4}{|c|}{ Carbon-limited } & \multicolumn{4}{|c|}{ Nitrogen-limited } \\
\hline & $\begin{array}{l}\text { Total } \\
\text { activity } \\
(\mathrm{T}) \\
\text { in crude }\end{array}$ & $\begin{array}{c}P_{1}+P_{2} \\
(\%)\end{array}$ & $\underset{(\%)}{S}$ & $\begin{array}{c}\text { Recovery } \\
(\%)\end{array}$ & $\begin{array}{c}\text { Total } \\
\text { activity } \\
(\mathrm{T}) \\
\text { in crude }\end{array}$ & $\begin{array}{c}\mathbf{P}_{1}+\mathbf{P}_{2} \\
(\%)\end{array}$ & $\begin{array}{c}S \\
(\%)\end{array}$ & $\begin{array}{c}\text { Recovery } \\
(\%)\end{array}$ \\
\hline \multicolumn{9}{|l|}{ Ammonium as nitrogen source } \\
\hline Citrate synthase & $11 \cdot 6$ & 23 & 77 & 40 & $15 \cdot 6$ & 23 & 77 & 88 \\
\hline Alkaline phosphatase & $2 \cdot 5$ & 8 & 92 & 74 & $10 \cdot 3$ & 1 & 99 & 101 \\
\hline Valine aminotransferase & $105 \cdot 5$ & 3 & 97 & 86 & $90 \cdot 0$ & 2 & 98 & 76 \\
\hline Pyruvate decarboxylase & $2 \cdot 4$ & 9 & 91 & 132 & $24 \cdot 6$ & 1 & 99 & 93 \\
\hline Alcohol dehydrogenase & $13 \cdot 6$ & 25 & 75 & 79 & $34 \cdot 1$ & 3 & 97 & 88 \\
\hline Protein & $57 \cdot 6$ & 11 & 89 & 66 & $120 \cdot 3$ & 6 & 94 & 76 \\
\hline \multicolumn{9}{|l|}{ Valine as nitrogen source } \\
\hline Citrate synthase & $72 \cdot 0$ & 3 & 97 & 88 & $6 \cdot 8$ & 13 & 87 & 88 \\
\hline Alkaline phosphatase & $1 \cdot 1$ & 5 & 95 & 70 & $18 \cdot 2$ & 2 & 98 & 57 \\
\hline Valine aminotransferase & $91 \cdot 0$ & 8 & 92 & 121 & $141 \cdot 9$ & 4 & 96 & 82 \\
\hline Pyruvate decarboxylase & 1.7 & ND & ND & ND & $5 \cdot 5$ & 0 & 100 & 77 \\
\hline Alcohol dehydrogenase & $1 \cdot 2$ & ND & ND & ND & 0.4 & ND & ND & ND \\
\hline Protein & $56 \cdot 2$ & 6 & 94 & 120 & 51.9 & 2 & 98 & 68 \\
\hline
\end{tabular}

ND, Not determined.

from glutamate (formed by the action of valine aminotransferase). Similar results for this enzyme were obtained by Zwart et al. (1983) during growth of $C$. utilis in continuous culture on L-alanine. The recorded levels of pyruvate decarboxylase in Table 1 are in good agreement with the data of Van Urk et al. (1989), but our alcohol dehydrogenase activities are lower, due to different assay conditions. The levels of aminotransferase activity are adequate to account for the observed levels of nonpyruvate keto acids.

\section{Subcellular location of the enzymes of the Ehrlich pathway during different growth conditions}

It is known that the branched-chain amino acid aminotransferase of mammalian tissue varies in its subcellular location according to the metabolic role of the tissue, so that when the enzyme has a biosynthetic role, e.g. in brain or white muscle, it is located in the cytosol, and when it has a degradative role, e.g. in heart, it is located in the mitochondria (Hutson, 1988). In Neurospora crassa, separate branched-chain amino acid aminotransferases (with slightly different substrate specificities) exist in cytosol and mitochondria, with the cytosolic enzyme being thought to be involved in amino acid breakdown and the mitochondrial enzyme in biosynthesis (Collins \& Wagner, 1973). In yeast, the enzymes of isoleucine and valine biosynthesis are known to be mitochondrial (Ryan \& Kohlhaw, 1974), but nothing is known of the subcellular location of the enzymes of the Ehrlich pathway (Bigelis et al., 1983). Ryan et al. (1973) obtained evidence that the glutamate:2-oxoisocaproate aminotransferase activity of baker's yeast was located in both cytosolic and particulate cell fractions.

It thus seemed plausible that the subcellular distribution of branched-chain amino acid aminotransferase might change between conditions in which it has a degradative role such as growth on valine as the sole nitrogen source, and conditions in which it has a biosynthetic role, such as when ammonium serves as sole nitrogen source. Tables 2 and 3 report the distribution of the three enzymes of the Ehrlich pathway, the mitochondrial marker enzyme citrate synthase and the nonsedimenting marker enzyme, alkaline phosphatase (Jenkins et al., 1983) during the various growth conditions. Pyruvate decarboxylase was found to be almost exclusively located in the cytosol in both organisms, in agreement with the work of Van Urk et al. (1989). Under all growth conditions and with both organisms, the distribution of valine aminotransferase closely followed that of alkaline phosphatase and pyruvate decarboxylase, leading us to conclude that it also was cytosolic (not sedimentable), and thus did not change its subcellular location under the different conditions studied, as suggested by Bigelis et al. (1983). It should be noted, however, that for certain of our spheroplast preparations, especially of $C$. utilis, the behaviour of the mitochondrial marker enzyme citrate synthase suggests that there has been significant lysis of the mitochondria. 
Table 4. Growth yields and steady-state concentrations of substrates and metabolites detected in the culture supernatants during growth of Saccharomyces cerevisiae in continuous culture under carbon or nitrogen limitation

\begin{tabular}{|c|c|c|c|c|}
\hline \multirow[b]{3}{*}{ Substrate or metabolite } & \multicolumn{4}{|c|}{ Concentration (mM) } \\
\hline & \multicolumn{2}{|c|}{ Ammonium as nitrogen source } & \multicolumn{2}{|c|}{ Valine as nitrogen source } \\
\hline & $\begin{array}{l}\text { Carbon } \\
\text { limitation }\end{array}$ & $\begin{array}{l}\text { Nitrogen } \\
\text { limitation }\end{array}$ & $\begin{array}{l}\text { Carbon } \\
\text { limitation }\end{array}$ & $\begin{array}{c}\text { Nitrogen } \\
\text { limitation }\end{array}$ \\
\hline $\begin{array}{l}\text { Culture } \mathrm{OD}_{540} \\
\text { Dry wt }\left(\mathrm{mg} \mathrm{ml}^{-1}\right)\end{array}$ & $\begin{array}{l}6 \cdot 2 \\
2 \cdot 28\end{array}$ & $\begin{array}{c}10 \cdot 0 \\
3 \cdot 88\end{array}$ & $\begin{array}{l}5 \cdot 6 \\
2 \cdot 03\end{array}$ & $\begin{array}{l}9 \cdot 2 \\
3 \cdot 54\end{array}$ \\
\hline $\begin{array}{l}\text { Substrates } \\
\text { Glucose in inflowing medium } \\
\text { Glucose in culture supernatant } \\
\text { Nitrogen source in inflowing medium } \\
\text { Nitrogen source in culture supernatant } \\
\text { Glucose metabolized (\%) } \\
\text { Nitrogen source metabolized (\%) }\end{array}$ & $\begin{array}{c}26 \cdot 0 \\
0 \\
20 \cdot 0 \\
9 \cdot 1 \\
100 \\
54\end{array}$ & $\begin{array}{r}235 \cdot 0 \\
10 \cdot 8 \\
20 \cdot 0 \\
0 \\
96 \\
100\end{array}$ & $\begin{array}{c}25 \cdot 2 \\
0 \\
24 \cdot 3 \\
9 \cdot 5 \\
100 \\
60\end{array}$ & $\begin{array}{r}218 \cdot 0 \\
9 \cdot 5 \\
21 \cdot 1 \\
0 \\
96 \\
100\end{array}$ \\
\hline $\begin{array}{l}\text { Molar growth yields [g dry wt (mol glucose } \\
\text { Glucose } \\
\text { Nitrogen source }\end{array}$ & $\begin{array}{l}\text { (n nitrogen })^{-1} \\
88 \\
209\end{array}$ & $\begin{array}{r}17 \\
194\end{array}$ & $\begin{array}{r}81 \\
137\end{array}$ & $\begin{array}{r}17 \\
168\end{array}$ \\
\hline $\begin{array}{l}\text { Metabolites } \\
\text { Pyruvate } \\
\text { Other keto acids } \\
\text { Acetate } \\
\text { Ethyl acetate }\end{array}$ & $\begin{array}{l}0.04 \\
0.14 \\
0.01 \\
0\end{array}$ & $\begin{array}{l}3 \cdot 68 \\
3 \cdot 21 \\
1.68 \\
0 \cdot 70\end{array}$ & $\begin{array}{l}0 \cdot 11 \\
1 \cdot 56 \\
0 \cdot 05 \\
0\end{array}$ & $\begin{array}{l}9 \cdot 80 \\
5 \cdot 00 \\
1.92 \\
7 \cdot 90\end{array}$ \\
\hline $\begin{array}{l}\text { Glycerol } \\
\text { Ethanol } \\
\text { 2-Methylpropanol } \\
\text { 2-Methylbutanol } \\
\text { 3-Methylbutanol }\end{array}$ & $\begin{array}{l}0.04 \\
0 \\
0 \\
0 \\
0\end{array}$ & $\begin{array}{c}2 \cdot 26 \\
150 \cdot 0 \\
0.45 \\
0.06 \\
0 \cdot 20\end{array}$ & $\begin{array}{l}0 \cdot 09 \\
0 \\
0 \\
0 \\
0\end{array}$ & $\begin{array}{c}1 \cdot 70 \\
158 \cdot 0 \\
7 \cdot 30 \\
0 \cdot 31 \\
0 \cdot 38\end{array}$ \\
\hline
\end{tabular}

The data for valine aminotransferase do not agree with the results of Ryan et al. (1973) for leucine aminotransferase in baker's yeast, where activity was found both in particulate $(80 \%)$ and supernatant $(20 \%)$ fractions of spheroplast lysates. It is possible that valine and leucine are metabolized by different aminotransferases, although there is some evidence to suggest that $S$. cerevisiae only contains a single aminotransferase for branched-chain amino acids (Dickinson \& Dawes, 1992). An alternative explanation may lie in differences of strain or growth conditions.

The presence of pyruvate decarboxylase and valine aminotransferase in the same subcellular compartment removes the possibility of control of biosynthesis and degradation of L-valine by subcellular compartmentation (Bigelis et al., 1983). In de novo biosynthesis of valine, the two enzymes will compete directly for 2-oxoisovalerate, and the most likely possible control is thus kinetic. No $K_{\mathrm{m}}$ values for branched-chain keto acids seem to have been reported, either for pyruvate decarboxylase or for any branched-chain amino acid aminotransferase (Ichihara, 1985), so it is not possible to predict the outcome of such competition. Our conclusion also implies that a transport mechanism must exist to allow de novo synthesized branched-chain keto acids to leave the mitochondria where they have been made (Ryan \& Kohlhaw, 1974).

Steady-state concentrations of products accumulated in the medium during continuous culture of $S$. cerevisiae

The shift to nitrogen limitation increased steady-state biomass concentration by $70 \%$, irrespective of nitrogen source (Table 4). It also caused the accumulation of ethanol, absent from the carbon-limited growth medium, at significant concentrations [ $150 \mathrm{~mm}$, equivalent to $0.7 \%$ $(\mathrm{w} / \mathrm{v})]$, so lowering the growth yield considerably, and produced a 100-fold increase in the concentration of pyruvate, irrespective of the nitrogen source. Less spectacular, but equally significant increases were observed in the steady-state concentrations of glycerol, acetate and ethyl acetate. The molar growth yields during nitrogen limitation were $194 \mathrm{~g}$ dry wt (g-atom nitrogen $)^{-1}$ for growth on ammonium and $168 \mathrm{~g}$ dry wt (g-atom nitrogen $)^{-1}$ for growth on valine. During respirofermentative metabolism $96 \%$ of the glucose was consumed, of which $23 \%$ was recovered as ethanol. Nitrogen limitation stimulated the steady-state concentration of non-pyruvate keto acids (assumed to be substantially 2 -oxoisovalerate) by 24 -fold during growth 
Table 5. Growth yields and steady-state concentrations of substrates and metabolites detected in the culture supernatants during growth of Candida utilis in continuous culture under carbon or nitrogen limitation

\begin{tabular}{|c|c|c|c|c|}
\hline \multirow[b]{3}{*}{ Substrate or metabolite } & \multicolumn{4}{|c|}{ Concentration (mM) } \\
\hline & \multicolumn{2}{|c|}{ Ammonium as nitrogen source } & \multicolumn{2}{|c|}{ Valine as nitrogen source } \\
\hline & $\begin{array}{l}\text { Carbon } \\
\text { limitation }\end{array}$ & $\begin{array}{c}\text { Nitrogen } \\
\text { limitation }\end{array}$ & $\begin{array}{l}\text { Carbon } \\
\text { limitation }\end{array}$ & $\begin{array}{r}\text { Nitrogen } \\
\text { limitation }\end{array}$ \\
\hline $\begin{array}{l}\text { Culture } \mathrm{OD}_{540} \\
\text { Dry wt }\left(\mathrm{mg} \mathrm{ml}^{-1}\right)\end{array}$ & $\begin{array}{l}5 \cdot 5 \\
1 \cdot 60\end{array}$ & $\begin{array}{c}12 \cdot 4 \\
3 \cdot 23\end{array}$ & $\begin{array}{l}4 \cdot 5 \\
1 \cdot 18\end{array}$ & $\begin{array}{l}9 \cdot 4 \\
3 \cdot 00\end{array}$ \\
\hline $\begin{array}{l}\text { Substrates } \\
\text { Glucose in inflowing medium } \\
\text { Glucose in culture supernatant } \\
\text { Nitrogen source in inflowing medium } \\
\text { Nitrogen source in culture supernatant } \\
\text { Glucose metabolized (\%) } \\
\text { Nitrogen source metabolized }(\%)\end{array}$ & $\begin{array}{c}27 \cdot 2 \\
0 \\
19 \cdot 8 \\
4 \cdot 4 \\
100 \\
78\end{array}$ & $\begin{array}{c}235 \\
165 \cdot 5 \\
18 \cdot 5 \\
0 \\
30 \\
100\end{array}$ & $\begin{array}{c}35 \\
0 \\
22 \cdot 1 \\
9 \cdot 1 \\
100 \\
59\end{array}$ & $\begin{array}{c}272 \\
192 \\
21 \cdot 4 \\
0 \\
30 \\
100\end{array}$ \\
\hline $\begin{array}{l}\text { Molar growth yields [g dry wt (mol glucose } \\
\text { Glucose } \\
\text { Nitrogen source }\end{array}$ & $\begin{array}{l}\text { (n nitrogen })^{-1} \\
59 \\
104\end{array}$ & $\begin{array}{r}47 \\
175\end{array}$ & $\begin{array}{l}34 \\
91\end{array}$ & $\begin{array}{r}38 \\
140\end{array}$ \\
\hline $\begin{array}{l}\text { Metabolites } \\
\text { Pyruvate } \\
\text { Other keto acids } \\
\text { Acetate }\end{array}$ & $\begin{array}{l}0.06 \\
0 \\
0\end{array}$ & $\begin{array}{l}3 \cdot 30 \\
9 \cdot 30 \\
2 \cdot 26\end{array}$ & $\begin{array}{l}0 \cdot 11 \\
0 \cdot 30 \\
0 \cdot 04\end{array}$ & $\begin{array}{l}2 \cdot 81 \\
6 \cdot 10 \\
2 \cdot 20\end{array}$ \\
\hline $\begin{array}{l}\text { Glycerol } \\
\text { Ethanol } \\
\text { 2-Methylpropanol } \\
\text { 2-Methylbutanol } \\
\text { 3-Methylbutanol }\end{array}$ & $\begin{array}{l}0 \\
0 \\
0 \\
0 \\
0\end{array}$ & $\begin{array}{l}0 \cdot 12 \\
0 \cdot 60 \\
0 \cdot 30 \\
0 \\
0\end{array}$ & $\begin{array}{l}0 \\
0 \\
0 \cdot 32 \\
0 \\
0\end{array}$ & $\begin{array}{l}0 \cdot 06 \\
3 \cdot 08 \\
3 \cdot 01 \\
0 \cdot 32 \\
0 \cdot 19\end{array}$ \\
\hline
\end{tabular}

on ammonium and by 3 -fold during growth on valine, as would be expected from the observations of Woodward \& Cirillo (1977). The corresponding data for the fusel alcohols shows that none were detectable if glucose was limiting in the culture, but that when glucose was in excess, i.e. under nitrogen limitation (Äyräpää, 1971), 2methylpropanol was the most important alcohol formed (as also observed during aerated growth by Guymon et al., 1961 b). More branched-chain alcohols were present when valine was the nitrogen source rather than ammonium, confirming the data of Watson \& Hough (1969) with leucine. The largest increase (16-fold) of the fusel alcohols is in 2-methylpropanol, as would be expected from its close relationship to valine, but 2methylbutanol and 3-methylbutanol were also increased (5.5-fold and 1.6-fold respectively).

\section{Steady-state concentrations of products accumulated in} the medium during continuous culture of $C$. utilis

In $C$. utilis grown under nitrogen limitation the steadystate pyruvate concentration was increased 28 - to 55 -fold (Table 5), and the increases in non-pyruvate keto acids were higher than in $S$. cerevisiae. The molar growth yields for nitrogen-limited growth were $175 \mathrm{~g}$ dry wt (g- atom nitrogen $)^{-1}$ for growth on ammonium and 140 for growth on valine. The lack of respirofermentative metabolism, typical of Crabtree-negative yeasts, means that only small quantities of ethanol were formed under nitrogen limitation, and only $30 \%$ of the glucose was consumed, irrespective of nitrogen source. Glycerol and ethyl acetate accumulation were insignificant. Acetate however accumulated to an even greater extent than in $S$. cerevisiae. The quantities and relative proportions of the three branched-chain alcohols were different in C. utilis, and the total amounts formed during steady-state growth under nitrogen limitation were about half those formed by $S$. cerevisiae. 2-Methylpropanol was detectable even in carbon-limited cells when valine was the nitrogen source, and in nitrogen-limited cells it was increased 10fold by valine. The methylbutanols were only found in nitrogen-limited growth on valine.

Effect of varying the growth rate on the accumulation of metabolites in the culture medium of $S$. cerevisiae growing on valine as sole nitrogen source under carbon limitation

During carbon-limited growth, at low growth rates, respiratory metabolism occurs, but when a critical 

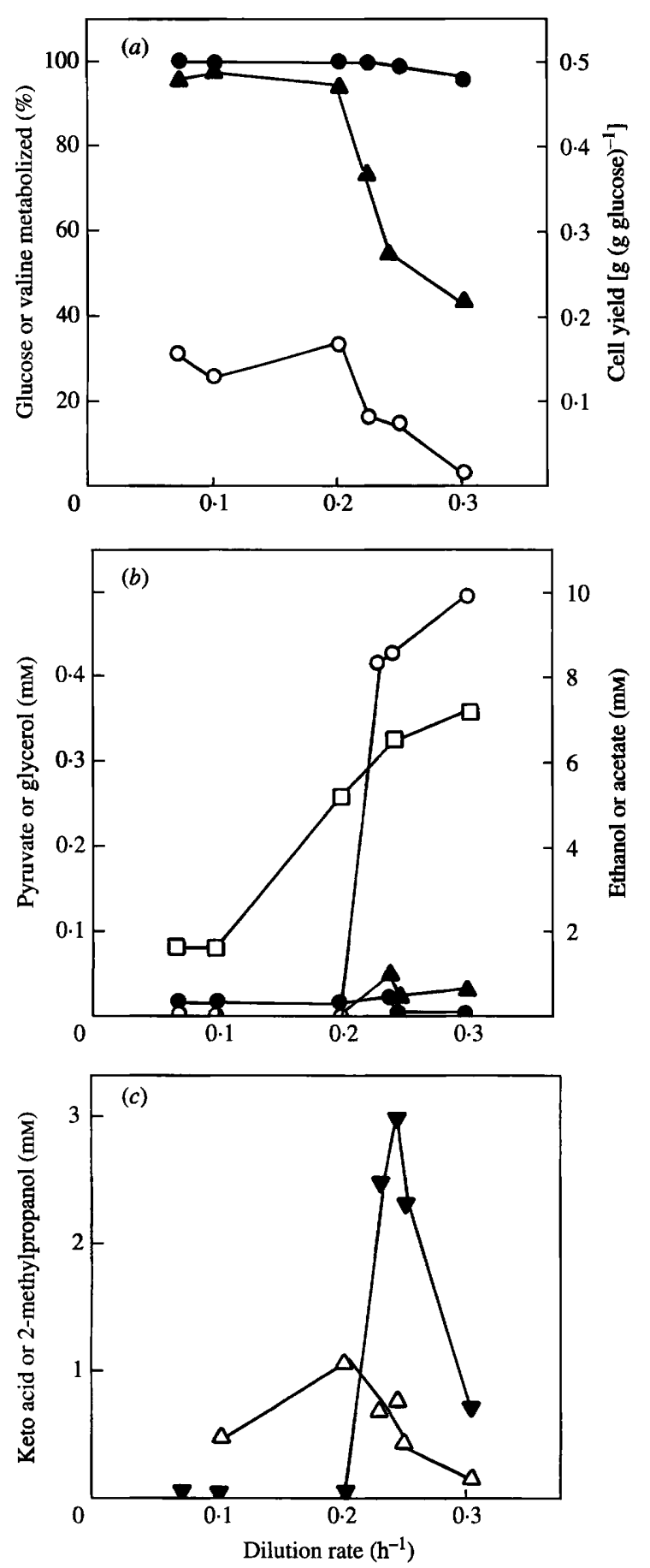

Fig. 1. Effect of dilution rate on the steady rate concentrations of substrates and fermentation products during growth of Saccharomyces cerevisiae on limiting glucose with L-valine as the nitrogen source. (a) $\Delta$, Cell yield [g (g glucose $\left.)^{-1}\right] ; \boldsymbol{O}$, percentage of glucose metabolized; $O$, percentage of valine metabolized; $(b)$ concentrations of metabolites in the medium: $\bigcirc$, ethanol; $\boldsymbol{O}$, glycerol; $\square$, pyruvate; $\boldsymbol{\Delta}$, acetate; $(c)$ $\boldsymbol{\nabla}$, 2-methylpropanol; $\Delta$, non-pyruvate keto acids.

dilution rate is exceeded, ethanol production is triggered, despite the aerobic conditions (respirofermentative growth), and this is accompanied by a drastic drop in the biomass produced (Fiechter et al., 1981; Postma et al., 1989). This approach enables branched-chain alcohol production to be studied under conditions in which glucose catabolite repression is minimized. The effect of growth rate on valine metabolism in $S$. cerevisiae was investigated by analysis of culture supernatants obtained from steady-state cultures with dilution rates in the range $0.07-0.3 \mathrm{~h}^{-1}$ at $27.8 \mathrm{~mm}$-glucose and $20 \mathrm{~mm}$-valine. Growth was carbon-limited up to $D=0.3 \mathrm{~h}^{-1}$ (Fig. $1 a$ ), where growth became limited by a medium component other than carbon or nitrogen, possibly sodium molybdate (Postma et al., 1989). Up to $D=0 \cdot 2 \mathrm{~h}^{-1}$, cell yield and the percentage of glucose and valine metabolized remained constant (Fig. 1 $a$ ) and the concentration of pyruvate in the medium increased (Fig. $1 b$ ); above this dilution rate, they decreased. The onset of ethanol and acetate production (Fig. $1 \mathrm{~b}$ ) and therefore of respirofermentative growth coincided with the decrease in biomass production observed above $D=0.2 \mathrm{~h}^{-1}$. The metabolites formed were lower in concentration than those observed in the work of Postma et al. (1989), in which ammonium was the nitrogen source, but the only significant difference that could be ascribed to a contribution from the carbon skeleton of valine was an increase in the production of non-pyruvate keto acids (assumed to be predominantly 2-oxoisovalerate) and a decrease in the biomass yield. Below the critical dilution rate of $0.2 \mathrm{~h}^{-1}$, the non-pyruvate keto acids increased with increasing growth rate, both as concentration in the supernatant (Fig. 1c) and also as proportion of the metabolized valine, but above $0 \cdot 2 \mathrm{~h}^{-1}$, they decreased along with the valine used, partly due to conversion to 2methylpropanol. The latter was only observed during respirofermentative growth and it increased in concentration with growth rate up to $D=0.24 \mathrm{~h}^{-1}$ before beginning to fall (Fig. 1c), although its production was constant relative to valine metabolized and biomass produced at all growth rates above $0 \cdot 2 \mathrm{~h}^{-1}$. No methylbutanols were detected. Our observations are essentially in agreement with those of Postma et al. (1989). Our lower critical dilution rate $\left(0.2 \mathrm{~h}^{-1}\right.$ as against $\left.0.38 \mathrm{~h}^{-1}\right)$ and the lower concentrations of metabolites produced cannot be due to the lower glucose concentration used in the present study (Rieger et al., 1983). It seems probable that they are due to the higher energy requirement when valine is used as nitrogen source. However, our data are supported by recent work by Larsson et al. (1993), using S. cerevisiae CBS 246, who observed an identical critical dilution rate for transition to respirofermentative growth of $0.2 \mathrm{~h}^{-1}$ during glucose-limited growth at high ammonium concentrations. The decrease in glycerol formed at dilution rates above $0.24 \mathrm{~h}^{-1}$ (Fig. $1 b$ ) may relate to the increase in branched-chain alcohols (Quain \& Duffield, 1985). 
Relationship of the measured enzyme activities to the concentration of branched-chain alcohols formed

It can be calculated from the enzyme activities in Table 1 and the rate of biomass synthesis (assuming a 50\% protein content), that the rate of synthesis of all the three enzymes of the Ehrlich pathway is in all the conditions studied and in both organisms more than sufficient to account for the concentration of branched-chain alcohols formed. It seems unlikely that the activity of valine aminotransferase is a controlling element, since in $C$. utilis where it is much more active, the concentrations of fusel alcohols accumulating are actually lower than in $S$. cerevisiae. It is clear that despite the significant differences in enzyme specific activities between the two yeasts, the differences in the concentration of fusel alcohols between the two species $S$. cerevisiae and $C$. utilis cannot be explained on this basis.

\section{Fate of valine as nitrogen source}

The decreased molar biomass yield in both organisms during growth on valine suggests that the carbon skeleton of valine is not contributing to cell biomass, and also that the assimilation of valine nitrogen places an additional energy requirement on the cell. In $S$. cerevisiae, the 2methylpropanol formed during nitrogen-limited growth only accounts for $37 \%$ of the carbon of the valine that has been used. Even if it is assumed that all the additional pyruvate and other keto acids formed at high glucose concentration also arise from valine, more than $30 \%$ of the valine consumed is still unaccounted for, possibly as metabolites not measured, since the cellular carbon has not increased. One possible explanation of this is that at least some of the valine used has been metabolized via some other metabolic route. Such a route might be the branched-chain 2-keto acid dehydrogenase system recently described in $S$. cerevisiae by Dickinson \& Dawes (1992). We have found that this enzyme system is indeed present, albeit at rather low activity, in $S$. cerevisiae but not $C$. utilis, grown in batch culture on the carbonlimiting medium (C. Wadforth \& P. J. Large, unpublished data). The suggestion is supported by the 23 -fold increase in specific activity of branched-chain amino acid aminotransferase during carbon-limited growth on valine (Table 1). In C. utilis, the branched-chain 2-keto acid dehydrogenase pathway, if present, might account for an even greater proportion of the valine metabolized, since in C. utilis $85 \%$ of the valine carbon is not accounted for. However, since no special precautions were taken to prevent volatile metabolites being stripped from the medium by the aerating air, it is not possible to exclude losses by volatilization as contributing to the poor recoveries of these metabolites (although the ethanol would be more significantly affected than the branchedchain alcohols). More data will be necessary to establish for certain whether or not valine contributes to biomass cell build-up. Further work using $\left[{ }^{14} \mathrm{C}\right]$ valine and kinetic studies of the aminotransferase, decarboxylase and branched-chain keto acid dehydrogenase will also be necessary to establish for certain the relative contribution of different metabolic routes to the fate of valine.

We thank Anne Robertson for her skilled technical assistance, Cath Wadforth for the drawings and Hans van Dijken for his advice in the early stages of this work, which was funded by the Agricultural and Food Research Council, Swindon (Grant FG21/502), whose support is gratefully acknowledged.

\section{References}

AKI, K. \& ICHIHARA, A. (1970). Branched-chain amino acid aminotransferase (pig heart mitochondria). Methods in Enzymology 17A, 807-811.

AleXANDER, M. A. \& JefFries, T. W. (1990). Respiratory efficiency and metabolite partitioning as regulatory phenomena in yeasts. Enzyme and Microbial Technology 12, 2-19.

ÄYRÄPÄÄ, T. (1971). Biosynthetic formation of higher alcohols by yeast. Dependence on the nitrogenous nutrient level of the medium. Journal of the Institute of Brewing 77, 266-276.

BERGMEYER, H.-U. (1963). Glucose-6-phosphate dehydrogenase. In Methods of Enzymatic Analysis, pp. 744-751. Weinheim: Verlag Chemie.

BerRy, D. R. \& Chamberlain, H. (1986). Formation of organoleptic compounds by yeast grown in continuous culture in defined medium Journal of the American Society of Brewing Chemists 44, 52-56.

BerRY, D. R. \& WATSON, D. C. (1987). Production of organoleptic compounds. In Yeast Biotechnology, pp. 345-368. Edited by D. R. Berry, I. Russell \& G. G. Stewart. London: Allen \& Unwin.

Bigelis, R., Weir, P. D., Jones, R. R. M. \& Umbarger, H. E. (1983). Exogenous valine reduces conversion of leucine to 3-methyl-1butanol in Saccharomyces cerevisiae. Applied and Environmental Microbiology 45, 658-664.

Bode, R. \& Birnbaum, D. (1988). Purification and properties of two branched-chain amino acid aminotransferases from the yeast Candida maltosa. Biochemie und Physiologie der Pflanzen 183, 417-424.

BRADFORD, M. M. (1976). A rapid and sensitive method for the quantitative determination of microgram quantities of protein using the principle of protein-dye binding. Analytical Biochemistry $\mathbf{7 2}$ 248-254.

Bruinenberg, P. M., van Dijken, J. P. \& Scheffers, W. A. (1983). An enzymic analysis of NADPH production and consumption in Candida utilis. Journal of General Microbiology 129, 965-971.

Bruinenberg, P. M., van Dijken, J. P., Kuenen, J. G. \& Scheffers, W. A. (1985). Critical parameters in the isolation of mitochondria from Candida utilis grown in continuous culture. Journal of General Microbiology 131, 1035-1042.

Chaney, A. M. \& Marbach, E. P. (1962). Modified reagents for the determination of urea and ammonia. Clinical Chemistry 8, 130-132.

Clarkson, S. P., Large, P. J., Boulton, C. A. \& Bamforth, C. W. (1991). Synthesis of superoxide dismutase, catalase and other enzymes and oxygen and superoxide toxicity during changes in oxygen concentration in cultures of brewing yeast. Yeast 7, 91-103.

Collins, M. \& WAGNER, R. P. (1973). Branched chain amino acid aminotransferases of Neurospora crassa. Archives of Biochemistry and Biophysics 155, 184-193.

DiCkinson, J. R. \& DAWES, I. W. (1992). The catabolism of branchedchain amino acids occurs via 2-oxoacid dehydrogenase in Saccharomyces cerevisiae. Journal of General Microbiology 138, 2029-2033. 
DOHERTY, D. (1970). L-Glutamate dehydrogenases (yeast). Methods in Enzymology 17A, 850-856.

EHRLICH, F. (1907). Über die Bedingungen der Fuselölbildung und über ihren Zusammenhang mit dem Eiweissaufbau der Hefe. Berichte der Deutschen Chemischen Gesellschaft 40, 1027-1047.

ENGAN, S. (1981). Beer composition: volatile substances. In Brewing Sciences, vol. 2, pp. 98-105. Edited by J. R. A. Pollock. London: Academic Press.

FieCHTER, A., FuHRMANN, G. F. \& KäPPELLI, O. (1981). Regulation of glucose metabolism in growing yeast cells. Advances in Microbial Physiology 22, 123-183.

GREEN, J. \& LARGE, P. J. (1984). Subcellular localization and properties of partially purified dimethylamine and trimethylamine monooxygenase activities in Candida utilis. Journal of General Microbiology 130, 2577-2588.

Guymon, J. F., Ingraham, J. L. \& Crowell, E. A. (1961a). The formation of $n$-propyl alcohol by Saccharomyces cerevisiae. Archives of Biochemistry and Biophysics 95, 163-168.

GuYmon, J. F., IngrahaM, J. L. \& Crowell, E. A. (1961 b). Influence of aeration upon the formation of higher alcohols by yeast. American Journal of Enology and Viticulture 12, 60-66.

Hutson, S. M. (1988). Subcellular distribution of branched-chain aminotransferase activity in rat tissues. Journal of Nutrition 118, $1475-1481$

ICHIHARA, A. (1985). Aminotransferases of branched-chain amino acids. In Transaminases, pp. 430-439. Edited by P. Christen \& D. E. Metzler. New York: John Wiley \& Sons.

INGRAHAM, J. L. \& GUYMON, J. F. (1960). The formation of higher aliphatic alcohols by mutant strains of Saccharomyces cerevisiae. Archives of Biochemistry and Biophysics 95, 163-168.

Jenkins, R. O., Cartledge, T. G. \& Lloyd, D. (1983). Subcellular fractionation of Candida stellatoidea after growth with glucose or $n$ hexadecane. Journal of General Microbiology 129, 1171-1185.

LARGE, P. J. (1986). Degradation of organic nitrogen compounds by yeasts. Yeast 2, 1-34.

LARGe, P. J. \& RoBertson, A. (1988). The subcellular location of 4aminobutyrate aminotransferase in Candida boidinii and its probable role in the breakdown of putrescine and spermidine. Yeast 4, $149-153$.

Larsson, C., von Stockar, U., Marison, I. \& Gustafsson, L. (1993). Growth and metabolism of Saccharomyces cerevisiae in chemostat cultures under carbon-, nitrogen-, or carbon- and nitrogen-limiting conditions. Journal of Bacteriology 175, 4809-4816.

MacDonald, J., Reeve, P. T. V., Ruddlesden, J. D. \& White, F. H. (1984). Current approaches to brewery fermentations. Progress in Industrial Microbiology 19, 47-198.

McGill, D. J. \& DaWES, E. A. (1971). Glucose and fructose metabolism in Zymomonas anaerobia. Biochemical Journal 125, 1059-1068.

Massey, L. K., SoKatch, J. R. \& ConRad, R. S. (1976). Branchedchain amino acid catabolism in bacteria. Bacteriological Reviews 40 , $42-54$.
Miller, S. M. \& Magasanik, B. (1990). Role of NAD-linked glutamate dehydrogenase in nitrogen metabolism in Saccharomyces cerevisiae. Journal of Bacteriology 172, 4927-4935.

Postma, E., Verduyn, C., Scheffers, W. A. \& van Dijken, J. P. (1989). Enzymic analysis of the Crabtree effect in glucose-limited chemostat cultures of Saccharomyces cerevisiae. Applied and Environmental Microbiology 55, 468-477.

QuAIN, D. E. \& DuFfield, M. L. (1985). A metabolic function for higher alcohol production by yeast. European Brewery Convention: Proceedings of the 20th Congress, Helsinki, pp. 307-314. Oxford: IRL Press.

RIEGER, M., KÄPPELI, O. \& FIECHTER, A. (1983). The role of limited respiration in the incomplete oxidation of glucose by Saccharomyces cerevisiae. Journal of General Microbiology 129, 653-661.

RYAN, E. D. \& KohlHaW, G. B. (1974). Subcellular localization of the isoleucine-valine biosynthetic enzymes in yeast. Journal of Bacteriology 120, 631-637.

Ryan, E. D., Tracy, J. W. \& Kohlhaw, G. B. (1973). Subcellular localization of the leucine biosynthetic enzymes in yeast. Journal of Bacteriology 116, 222-225.

Satake, K., OkuYama, T., Ohashi, M. \& Shinoda, T. (1960). The spectrophotometric determination of amine, amino acid and peptide with 2,4,6-trinitrobenzene 1-sulfonic acid. Journal of Biochemistry 47, 654-660.

Scotr, J. H. \& Schekman, R. (1980). Lyticase: endoglucanase and protease activities that act together in yeast cell lysis. Journal of Bacteriology 142, 414-423.

SentHEShanMuganathan, S. (1960). The mechanism of the formation of higher alcohols from amino acids by Saccharomyces cerevisiae. Biochemical Journal 74, 568-576.

SINGH, R. \& KunKEE, R. E. (1977). Multiplicity and control of alcohol dehydrogenase isoenzymes in various strains of wine yeasts. Archives of Microbiology 114, 255-259.

Skoneczny, M., Chelstowska, A. \& RytKa, J. (1988). Study of the coinduction by fatty acids of catalase A and acyl-CoA oxidase in standard and mutant Saccharomyces cerevisiae strains. European Journal of Biochemistry 174, 297-302.

VAN URK, H., SCHIPPER, D., BReEDVELd, G. J., MAK, P. R., SChefFers, W. A. \& VAN DIJKEN, J. P. (1989). Localization and kinetics of pyruvate-metabolizing enzymes in relation to aerobic alcoholic fermentation in Saccharomyces cerevisiae CBS 8066 and Candida utilis CBS 621. Biochimica et Biophysica Acta 992, 78-86.

WATSON, T. G. \& Hough, J. S. (1969). Conversion of $\alpha$-keto-isocaproic acid to iso-amyl alcohol by yeast pyruvate decarboxylase and alcohol dehydrogenase. Journal of the Institute of Brewing 75, 359-363.

WebB, A. D. \& Ingraham, J. L. (1963). Fusel oil. Advances in Applied Microbiology 5, 317-353.

WoOdWARD, J. R. \& Cirillo, V. P. (1977). Amino acid transport and metabolism in nitrogen-starved cells of Saccharomyces cerevisiae. Journal of Bacteriology 130, 714-723.

ZWART, K. B., Overmars, E. H. \& Harder, W. (1983). The role of peroxisomes in the metabolism of D-alanine in the yeast Candida utilis. FEMS Microbiology Letters 19, 225-231. 